\title{
An Analysis of Information Materiality on Corporate Sustainability Report Using Information Materiality Map: A Review in Mining Industry in Indonesia
}

\author{
Putu Sukma Kurniawan \\ Department of Accounting, Faculty of Economics \\ Universitas Pendidikan Ganesha, Singaraja, Bali, Indonesia \\ putusukma1989@gmail.com
}

\begin{abstract}
This research aims to provide an overview of information that is material in sustainability reporting in Indonesia, especially material information in sustainability report in mining industry in Indonesia. The design of this research is document analysis. In this context, this study try to achieve an understanding of the document's contents from corporate sustainability report. This research used sustainability report published by companies in mining industry fields, particularly mining companies which competed in Indonesia Sustainability Reporting Award (ISRA) in 2014, 2015 and 2016. Data was collected by secondary data through the official website of Indonesia Stock Exchange as well as the company's official website. The data of sustainability reports were analyzed descriptively by analyzing the content of the sustainability report. This study can help to build a new perspective about material information in sustainability report in Indonesian mining industry.

Keywords: Information Materiality Map, Sustainability Reporting, Sustainability Report, Mining Industry
\end{abstract}

\section{Introduction}

Sustainability report becomes a new paradigm in corporate reporting process. Sustainability report is a new evolution of corporate reporting. In the beginning at the process of reporting, companies management is still focus on financial statements that contain financial figures. A company's performance is still based on financial figures or based on accounting numbers. The new paradigm assumes that the financial figures or accounting numbers produced by the company can not guarantee the performance of companies in a comprehensive manner. The concept of sustainability can be interpreted that the company's management have a high interest about the consequences that may result from the company's business activities. In this case as well as social and environmental impacts that may arise. Braam et al. (2016) argue that companies management should have a high commitment about the impact of their business activities on the environment context. Based on the concept of sustainability, the performance of the company can be assessed comprehensively from economic performance, social performance, and environmental performance context.

Corporate sustainability report outlines contain information about economic performance, social performance and environmental performance of companies. Of course, the information presented in corporate sustainability report is information that represents the condition of the company from the perspective of sustainability concept. In general, companies management prepare their corporate sustainability report based on the GRI standards (Global Reporting Initiative standars), which has been changed into the GRI G4 standards. Brown et al. (2009) stated that the GRI framework is a 
comprehensive framework and perfect guideline for reporting social performance and environmental performance of companies. It is a voluntary standard for companies management for reporting their non-financial informations on social and environmental fields. GRI standard can be used as a guideline to crate a corporate sustainability report. In the concept of corporate reporting, there is a concept about information materiality. Zhou (2011) argues that the information materiality concept originally developed in the context of the company's financial reporting and now has applied in the concept of corporate sustainability reporting. The concept of information materiality will make the company's management to identify, select, and focus on sustainability issues and disclose an important informations to all stakeholders. Company's management will disclose some material informations which have a significant impact on the company's business activities.

The main reason this study uses mining industry as an object and focuses on the materiality of information on corporate sustainability report is based on several things, namely (1) some of literature explains that sustainability reporting is issued by the industries which bases its business operations can damage the environment. The mining industry is an industry which the main operating activities in this industry can produce damage to social community and environment. (2) The sustainability report covers three main issues, namely economic performance, social performance and environmental performance. In this context it is important to identify the social performance and the environmental performance of the mining industry. (3) The concept of information materiality is very important to know so we can present information that is required by stakeholders, which in this case are the stakeholders in the mining industry. The material information will greatly help all stakeholders in the context of decision making process. Another background underlying the writer choose the topic about information materiality is based on research conducted by GRI (Global Reporting Initiative) and RobecoSAM in 2015 that examined the materiality of information and its impact on the company's management and investors (GRI, 2015). GRI \& RobecoSAM research results (2015) provides benefits to strengthen the company's sustainability reporting process. Another benefit is that we can estimate the impact that may result from company's business activities to stakeholders (internal stakeholders and external stakeholders of the company). The focus of this study is to provide a new understanding in the context about information materiality in corporate sustainability report, particularly in mining industry in Indonesia. In helping to achieve the focus of this study, this research create an in-depth analysis and examine the sustainability report from mining industry in Indonesia.

This research aims to provide an overview of information that is material in sustainability reporting in Indonesia, especially material information in sustainability report in mining industry in Indonesia. This article is expected to contribute to the development of sustainability reporting process in Indonesia. The authors recognize that globally there has been a very significant development in the company's sustainability reporting process. It has been many companies management that realize the importance of corporate sustainability reporting process. Brown et al. (2009) states that the biggest benefit for company's management from sustainability reporting process is to maintain the reputation management and protect the company brand. And also to improve the relationship quality with companies stakeholders. The motivation of companies management to issue sustainability reports can be judged from the information presented in their sustainability report. If the management company disclose the 
information that is really needed by their stakeholders, then it is a true motivation of management to provide comprehensive information to stakeholders, not just to improve their company brand in stakeholder's perspective. The implications of this study are expected to provide insight to the company's management regarding material information in corporate sustainability report, particularly in the mining industry. The results of this research may also provide benefits to prospective investors where potential investors can create more comprehensive assessment on companies. The potential investors in their decision making process, not only concern the material information in company's economic performance, but can also consider material information in company's social performance and company's environmental performance. This study can help to build a new perspective about material information in sustainability report in Indonesian mining industry.

\section{Literature Review}

\section{Material Information on Corporate Sustainability Report}

Sustainability report can be defined as a report containing company's economic performance, social performance, and environmental performance. The concept of sustainability is the principle concept in sustainability reporting context. The concept of sustainability explained that the company should contribute a real benefit to social community and environment and have a high concern in natural resources. In general, the concept of sustainability "forced" the company's management to think about the real impact of the company's business activities and management should contribute to their social community and environment around the company. Triple bottom lines concept can provide a deep perspective to management that the company should create a comprehensive analysis of impact which caused by companies business activities (Nuryaman, 2013). The concept of sustainability and the triple bottom lines concept are the basic principle in social and environmental accounting. Qureshi et al. (2012) stated that the social and environmental accounting become a trend because the attention to see the real performance from company's management in sustainability context.

Material information is important things to be served by the company's management in corporate sustainability report. The company's management should be able to determine which information is relevant for the company and for all stakeholders. This is because the information materiality influence the company's stakeholders in the decision making process context. Brown et al. (2009) found one way to make the non-financial information in a sustainability report become more important. Brown et al. (2009) argue that the financial sector (capital market) must be able to give more attention to the non-financial information. The results of that research, Brown et al. (2009) showed that institutional investors are still have a little attention in nonfinancial data or non-financial information. But the good news in this context is today many indexes in the stock market using concept of sustainability. The example of stock market based on the concept of sustainability such as the Dow Jones Sustainability Index which contribute to the increased use of information in a sustainability report. By conducting in-depth analysis of the performance of corporate in sustainability issue (economic performance, social performance, and environmental performance), investors can gain a better understanding of the quality of company's management and can predict the potential performance of the company in the future. This process will increase the ability of investors to identifying and estimating the value of their 
investment in the future. The quality of information on corporate sustainability report will determine the quality of investment decisions making process. Ernst \& Young report (2015) stated that $83 \%$ of companies in SGX top 50 reported aspects of sustainability as information which is material to the company and $63 \%$ of these companies provide evidence of how to identify issues in sustainability context. Results of research from Khan et al. (2016) states that companies which have a good level of disclosure in sustainability issues have a better performance in capital market than the company with lower level of disclosure in sustainability context. This fact suggests that the company's management should realized the importance of information related to the issue of sustainability in decision making process by investors and investors also had to response to sustainability issues that have been revealed by the company's management.

\section{Research Method}

The design of this research is document analysis. In this context, this study try to achieve an understanding of the document's contents from corporate sustainability report. This research method is based on research conducted by Naraduhita \& Sawarjuwono (2012), which used content analysis in their study. This analysis technique (content analysis) can be used to get a deeper understanding of the contents of a report in this context is the corporate sustainability report. The first stage in this research is create an analysis process to identify material information in sustainability report and subsequently prepared a information materiality map. This study was also based on the research conducted by Hsu et al. (2013) that create the materiality analysis model on corporate sustainability report. Hsu et al. (2013) argue that materiality analysis is important for management companies. That model can help companies management to determine the material issues in their sustainability report context. And also to enhance the quality of communication in the context of sustainability with their companies stakeholders.

The object of this study is sustainability reporting process in mining industry in Indonesia. This research used sustainability report published by companies in mining industry fields, particularly mining companies which competed in Indonesia Sustainability Reporting Award (ISRA) in 2014, 2015 and 2016. Indonesia Sustainability Reporting Award is a national competition to asses the companies sustainability report and this competition was held by National Center for Sustainability Reporting (NCSR). This study used corporate sustainability report in ISRA competition because the selection process in the competition had demonstrated or reflected the quality of sustainability reports produced by the companies management. Based on the data contained in the official website of ISRA, it can be found the information about the company in mining industry areas who won the ISRA competition. Based on the official website of ISRA then in 2014, 2015 and 2016, the mining companies that listed as the winner were PT. ANTAM (Persero) Tbk, PT. Indoraya Tambang Megah Tbk, and PT. Kaltim Prima Coal Tbk. Data was collected by secondary data through the official website of Indonesia Stock Exchange as well as the company's official website. Through the official website of Indonesia Stock Exchange and the company's official website, it can be found the sustainability report for three years from 2014 to 2016 for each company. 


\begin{tabular}{|c|c|c|}
\hline No. & Company Name & Sustainability Report Sample \\
\hline \multirow[t]{3}{*}{1} & \multirow[t]{3}{*}{ PT. ANTAM (Persero) Tbk. } & Sustainability Report 2014 \\
\hline & & Sustainability Report 2015 \\
\hline & & Sustainability Report 2016 \\
\hline \multirow[t]{3}{*}{2} & \multirow{3}{*}{$\begin{array}{l}\text { PT. Indoraya Tambang Megah } \\
\text { Tbk. }\end{array}$} & Sustainability Report 2014 \\
\hline & & Sustainability Report 2015 \\
\hline & & Sustainability Report 2016 \\
\hline \multirow[t]{3}{*}{3} & \multirow[t]{3}{*}{ PT. Kaltim Prima Coal Tbk. } & Sustainability Report 2014 \\
\hline & & Sustainability Report 2015 \\
\hline & & Sustainability Report 2016 \\
\hline
\end{tabular}

The data of sustainability reports were analyzed descriptively by analyzing the content of the sustainability report. The analysis is compiled by comparing the content of the sustainability report with the disclosure items contained in the GRI G4 reporting standard, particularly GRI G4 for the mining industry. On GRI G4 reporting standard, reporting standard for the mining industry called GRI G4 Disclosures Mining Sector.

\section{Data Analysis and Discussion}

\section{Material Information Characteristics in Sustainability Report in Mining Industry}

In this stage there will be identification process of material information in the mining industry context on corporate sustainability report sample. In general, GRI G4 Diclosures Mining Sector contains two types of reporting, public reporting (general standard disclosures) and custom reporting (specific standard disclosures). In every kind of reporting there are items that can be included on the sustainability report of mining industry. In general report, there is a general standard disclosure items, such as the analysis and strategy (strategy and analysis), the profile of the organization (organizational profile), the identification of the material aspect (identified material aspects and boundaries), relationships with the company's stakeholders (stakeholder engagement), governance (good corporate governance), and ethics and integrity (ethics and integrity in business context). In special report is divided into three types of disclosures, such as disclosure in economic aspects, disclosure in environmental aspects, and disclosure in social aspects. Disclosure in social aspects can be divided into several sub-categories, namely the practice of workers (labor practices), human rights (human rights in companies business activities), social attitudes (society), and product responsibility (product responsibility for customers). At this stage it will create an analysis of material information on each sustainability report that is used as a sample.

\section{Identification of Material Information on Sustainability Report PT. ANTAM (Persero) Tbk.}

This phase identifying the material information on sustainability report PT. ANTAM (Persero) Tbk. in 2014, 2015 and 2016. The companies management was used core approach to created the sustainability report. In sustainability report 2014, company's management has created a matrix that contained the material information for the company and the information is also important for the company's stakeholders. Matrix that contains material information is called a 
information materiality matrix. Information materiality matrix in sustainability report PT. ANTAM (Persero) Tbk. in 2014 has been described below.

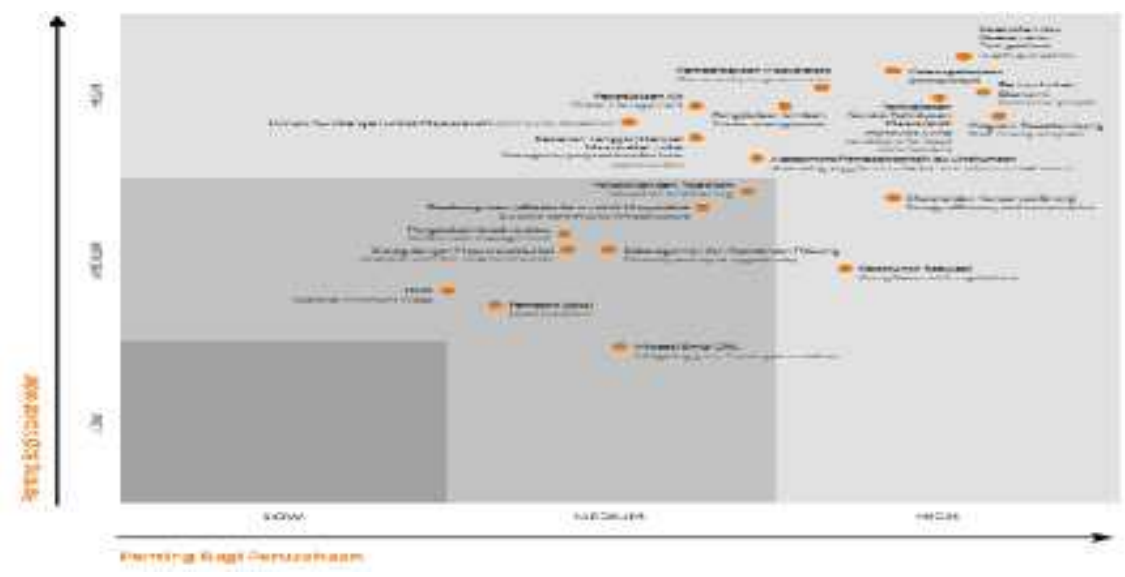

Figure 1. Information materiality matrix

Source: Sustainability Report PT. ANTAM (Persero) Tbk. (2014)

Based on figure 1, it can be understood that the management of PT. ANTAM (Persero) Tbk. has created a group of information in their sustainability report in accordance with the level of materiality. In figure 1, the information that has high level materiality is the information contained in the high and high quadrant, such as (1) occupational health and safety, (2) employment, (3) economic growth, (4) community empowerment, (5 ) post-mining program, (6) water and waste management, and (7) improving living conditions for local communities.

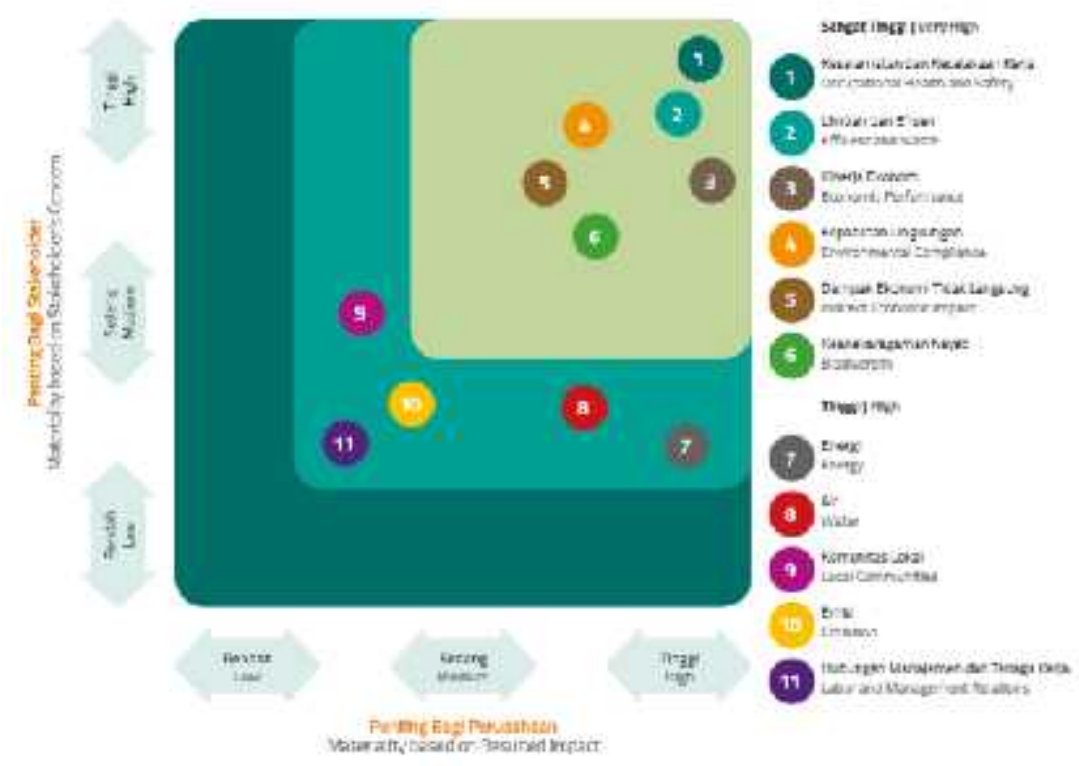

Figure 2. Information materiality matrix

Source: Sustainability Report PT. ANTAM (Persero) Tbk. (2015)

In the sustainability report of PT. ANTAM (Persero) Tbk. 2015, material informations are (1) occupation, health, and safety, (2) effluent and waste, (3) 
economic performance, (4) environmental compliance, (5) the indirect economic impact, and (6) biodiversity.

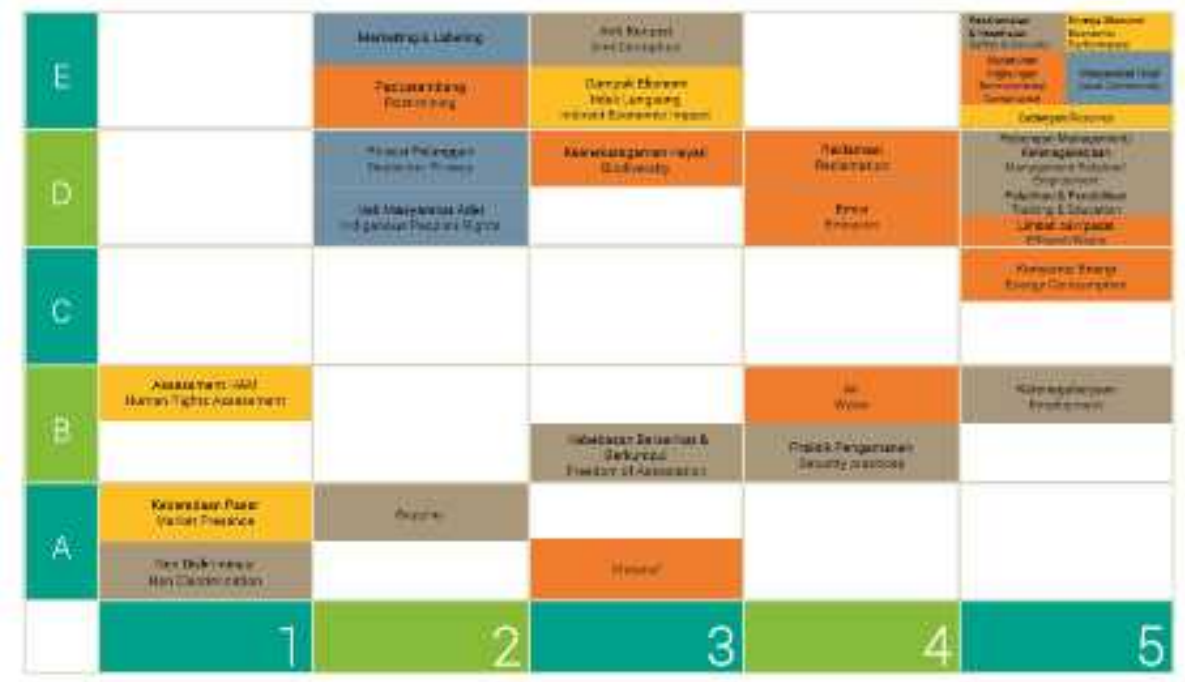

Figure 3. Information materiality matrix

Source: Sustainability Report PT. ANTAM (Persero) Tbk. (2016)

In the sustainability report of PT. ANTAM (Persero) Tbk. 2016, material informations are (1) occupation, health, and safety, (2) effluent and waste, (3) economic performance, (4) environmental compliance, (5) the indirect economic impact, ( 6) biodiversity, (7) training and education, (8) anti-corruption, and (9) energy comsumption.

\section{Identification of Material Information on Sustainability Report PT. Indoraya Tambang Megah Tbk.}

This stage identifying the material information on sustainability report of PT. Indoraya Tambang Megah Tbk. The companies management was used core approach to created the sustainability report. In assessing the material aspects, management has involved all employees and stakeholders of the company. Management of PT. Indoraya Tambang Megah Tbk. has made an information materiality matriks on sustainability report in 2014, 2015, and 2016.
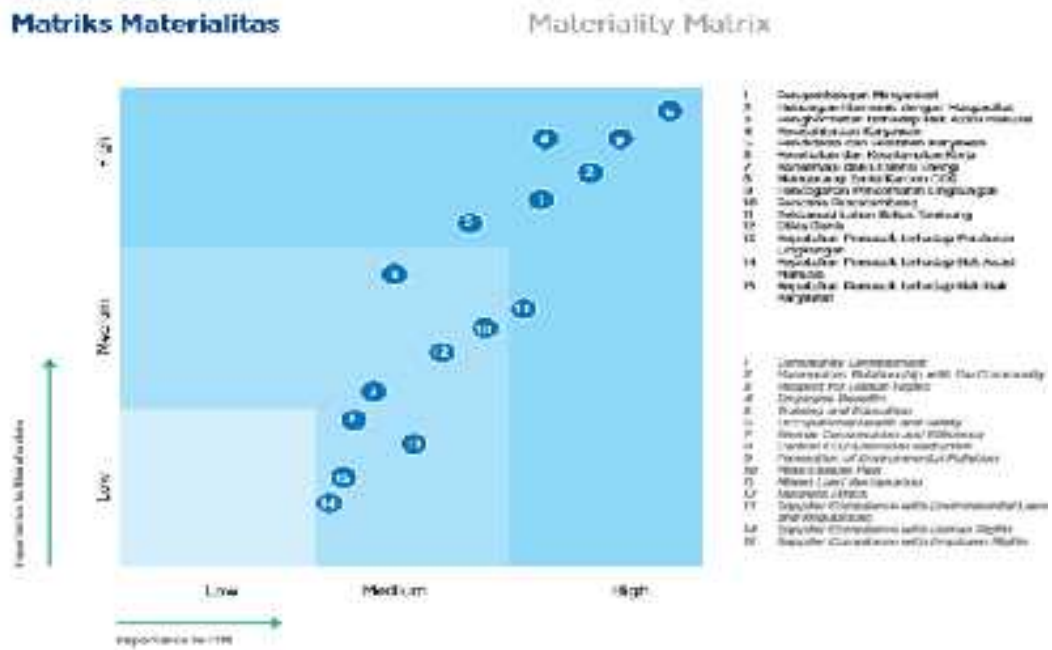
Figure 4. Information materiality matrix

Source: Sustainability Report PT. Indoraya Tambang Megah Tbk. (2014)

Based on information materiality matrix (figure 4), material information is information which contained in high and high quadrant. The material informations are (1) occupational health and safety, (2) prevention of environmental pollution, (3) employee benefits, (4) harmonious relationship with local communities, (5) community development, and (6) training and education.

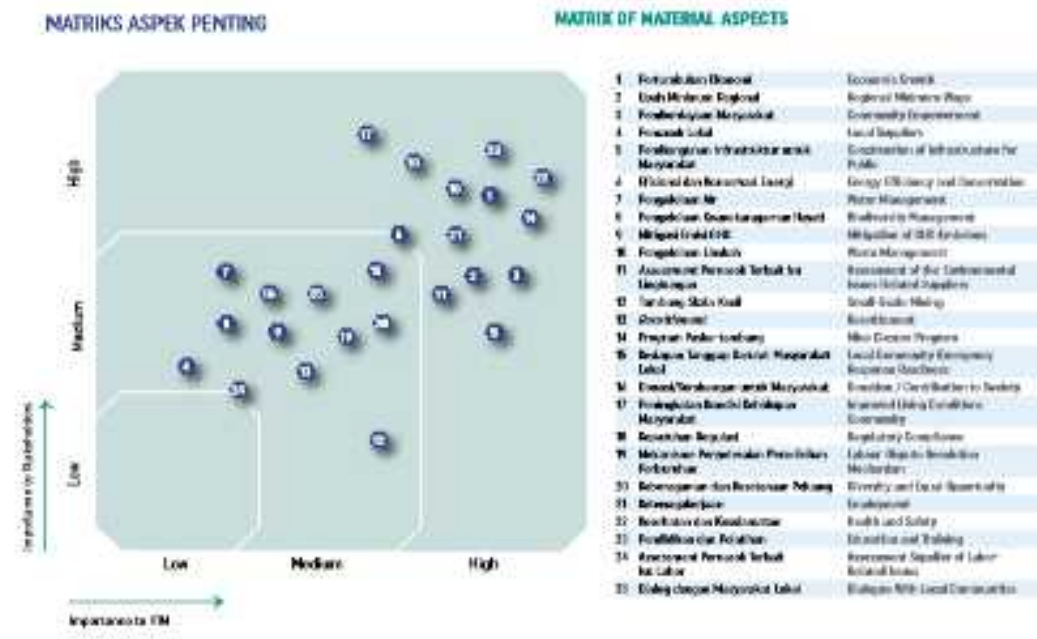

Figure 5. Information materiality matrix

Source: Sustainability Report PT. Indoraya Tambang Megah Tbk. (2015)

Based on the information materiality matrix in figure 5 , then the material informations are (1) education and training, (2) health and safety, (3) economic growth, (4) mine closure program, (5) waste management, (6) regulatory compliance, (7) the local living impoved commpunities, (8) community empowerment, and (9) employment.

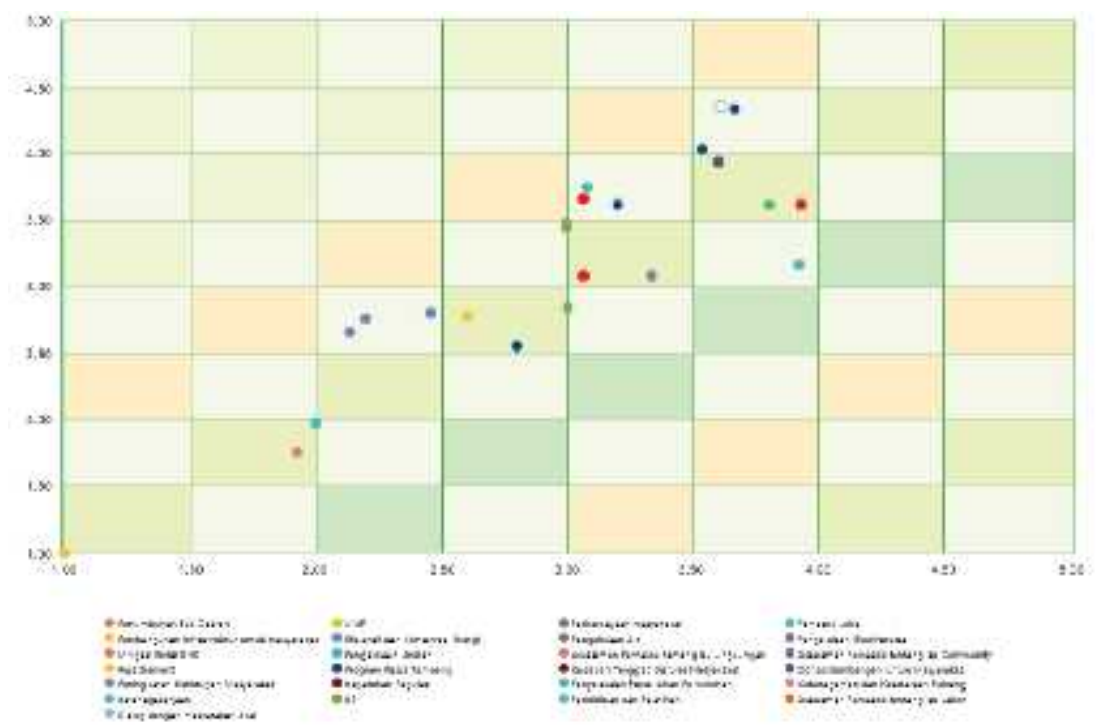

Figure 6. Information materiality matrix

Source: Sustainability Report PT. Indoraya Tambang Megah Tbk. (2016) 
Based on the information materiality matrix in figure 6, then the material informations are (1) education and training, (2) health and safety, (3) economic growth, (4) mine closure program, (5) waste management, (6) regulatory compliance, (7) the local living impoved commpunities, (8) community empowerment, and (9) employment.

\section{Identification of Material Information on the Sustainability Report PT Kaltim Prima Coal Tbk.}

Sustainability reports of PT Kaltim Prima Coal Tbk. in 2014, 2015, and 2016 using the GRI G4 Core approach and have been guaranteed by an independent auditor. The existence of the guarantee from independent auditor can certainly improve the credibility of corporate sustainability report. The management of PT Kaltim Prima Coal Tbk. has created a information materiality matrix for sustainability report in 2014, 2015, and 2016.

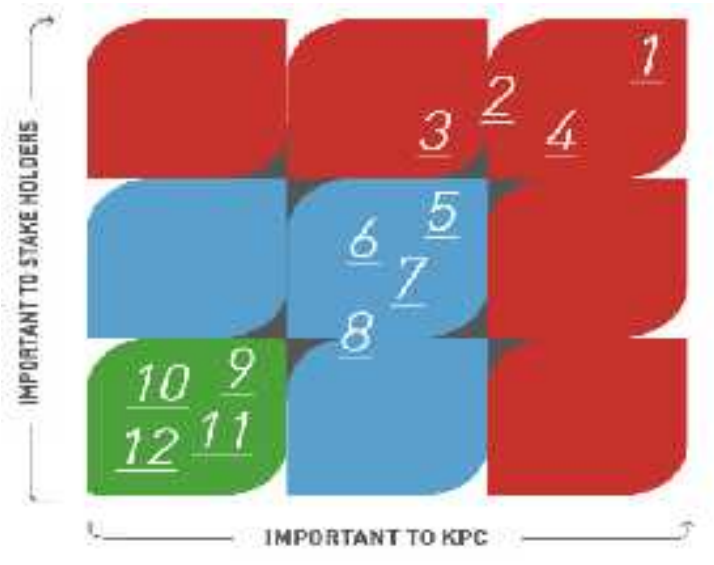

Figure 7. Information materiality matrix

Source: Sustainability Report PT Kaltim Prima Coal Tbk. (2014)

Based on the figure 7 , it can be understood that the material information contained in the high and high quadrant. The material informations are (1) a closure plan, (2) employee safety and health, (3) biodiversity protection, (4) local community engagement, (5) environmental management and performance, (6) economic growth, (7) labor training and development, and (8) socio-economic contribution. Management of PT Kaltim Prima Coal Tbk. in sustainability report in 2015 had made a information materiality matrix (figure 8).
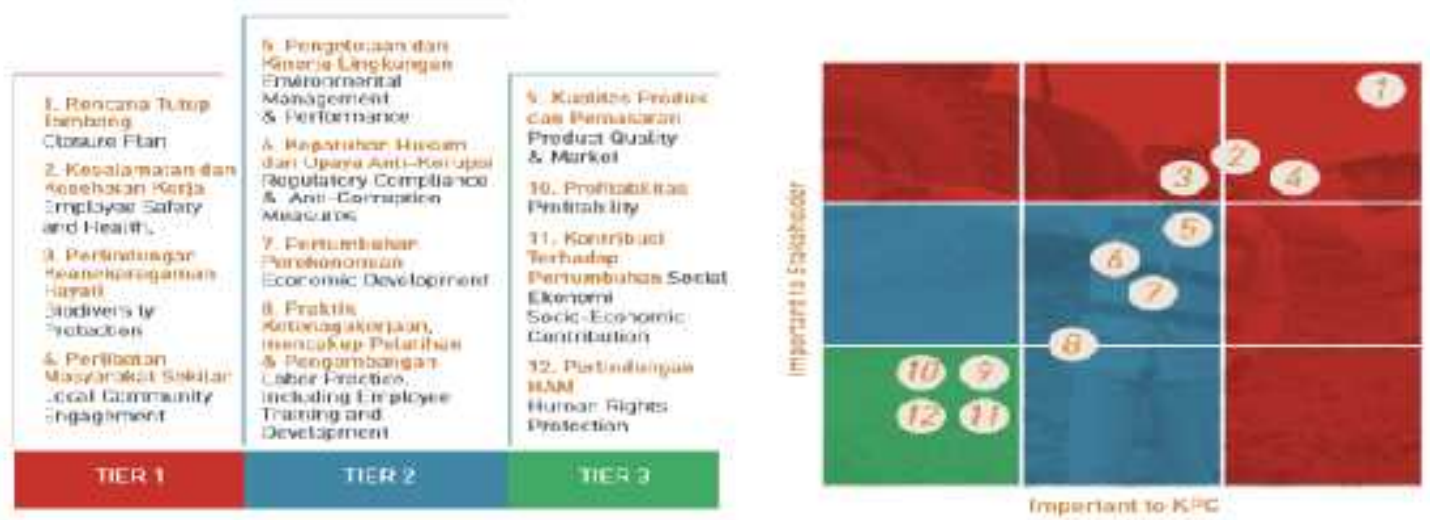
Figure 8. Information materiality matrix

Source: Sustainability Report PT Kaltim Prima Coal Tbk. (2015)

Based on the figure 8, it can be seen that the material information contained in high and high quadrant. The material informations are (1) a closure plan, (2) employee safety and health, (3) biodiversity protection, (4) local community engagement, (5) environmental management and performance, (6) economic growth, (7) labor training and development, and (8) socio-economic contribution.

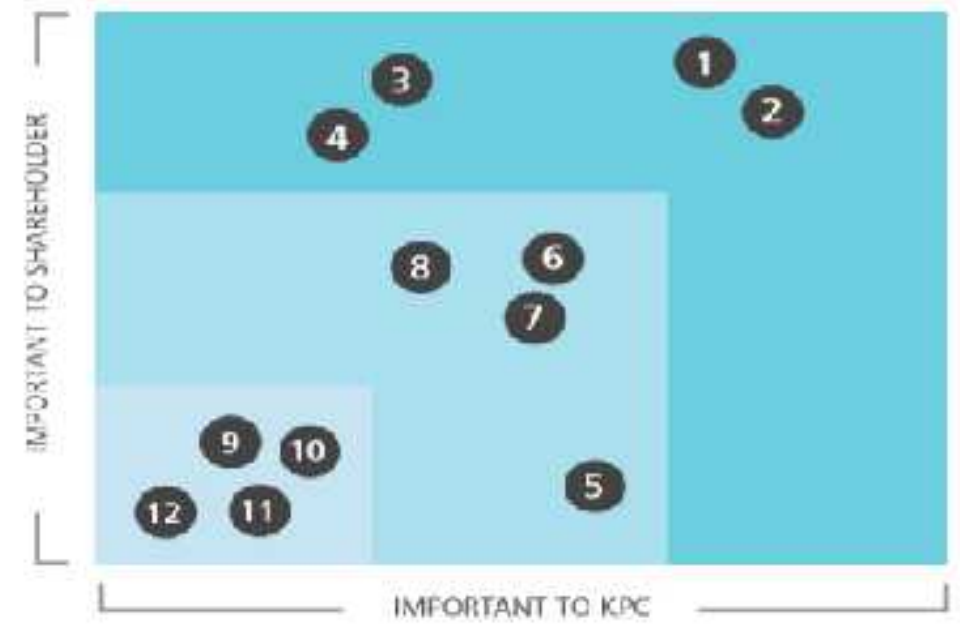

Figure 9. Information materiality matrix

Source: Sustainability Report PT Kaltim Prima Coal Tbk. (2016)

Based on the figure 9, it can be seen that the material information contained in the high and high quadrant. The material informations are (1) a closure plan, (2) employee safety and health, (3) biodiversity protection, (4) local community engagement, (5) environmental management and performance, (6) economic growth, (7) labor training and development, (8) socio-economic contribution, (9) product quality and market, and (10) human rights protection.

\section{A. Determining the level of significance of sustainability issues that have been identified using established criteria}

The significance level of sustainability issues that are material can be determined from the information materiality matrix contained in each corporate sustainability report. The information that has a high significance level (material information) can be determined by looking at the quadrants on the information materiality matrix. The informations contain in the high and high quadrant has a high impact to the company and their stakeholders. This kind of informations have a high level of significance (material information). Based on the information materiality matrix in each sustainability report, it can be created a list of material information in mining industry in Indonesia. 


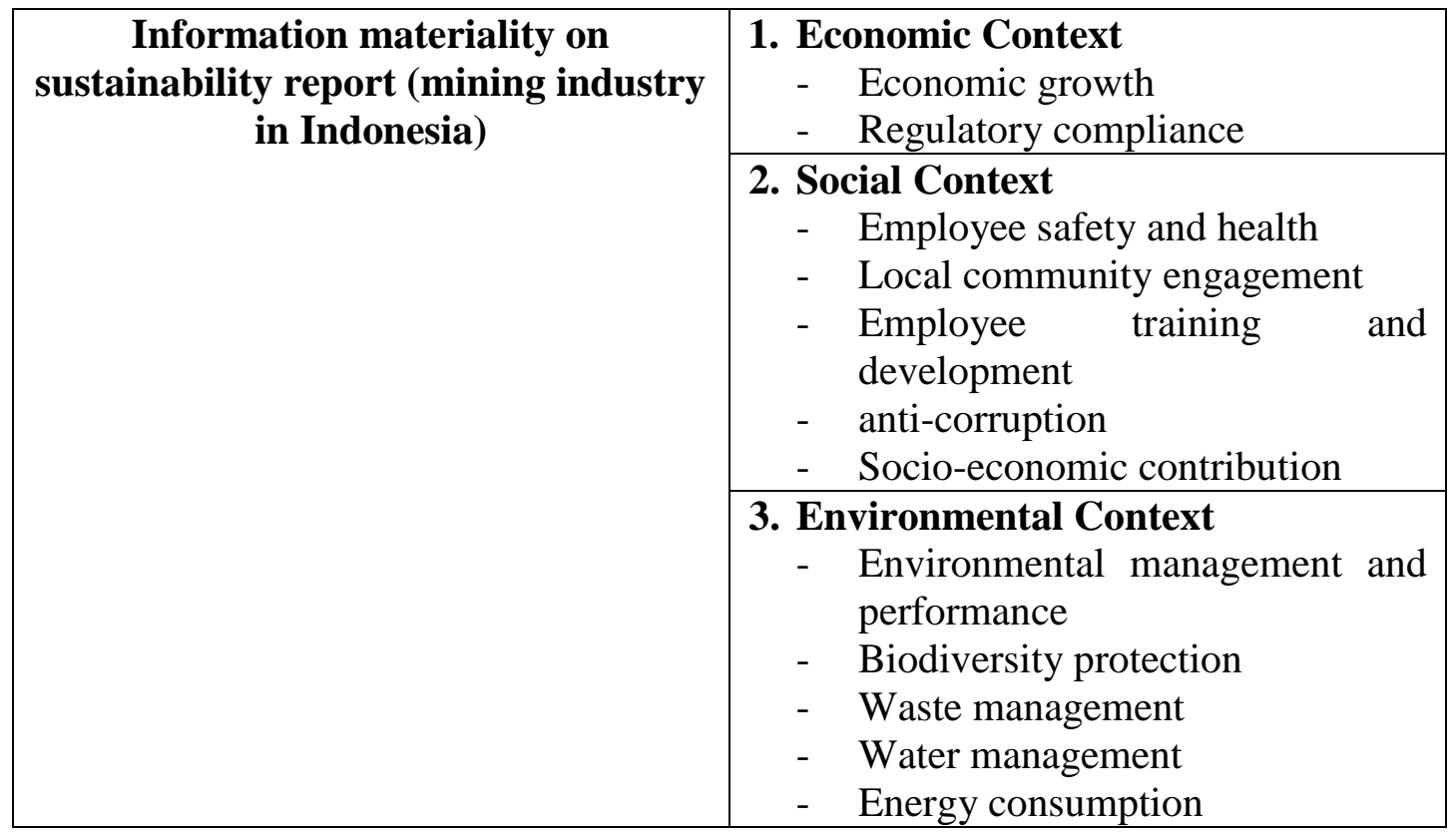

B. Identifying the impacts of corporate sustainability issues against the interests of all company's stakeholders

This stage identify the impact of sustainability issues (material information in sustainability context) in sustainability report to the interests of all stakeholders of the company. All companies management that report their sustainability areas have created the groups of their company's stakeholders. Management of PT. ANTAM (Persero) Tbk., PT. Indoraya Tambang Megah Tbk., and PT. Kaltim Prima Coal Tbk. have made a list of the company's stakeholders, such as (1) employees and unions, (2) NGOs and academic institutions, (3) central government, (4) local government and regulators, (5) investors and shareholders, (6) supplier and other business organizations, (7) local community and society, and (8) consumers. Below is the chart of stakeholder groups in the mining industry in Indonesia.

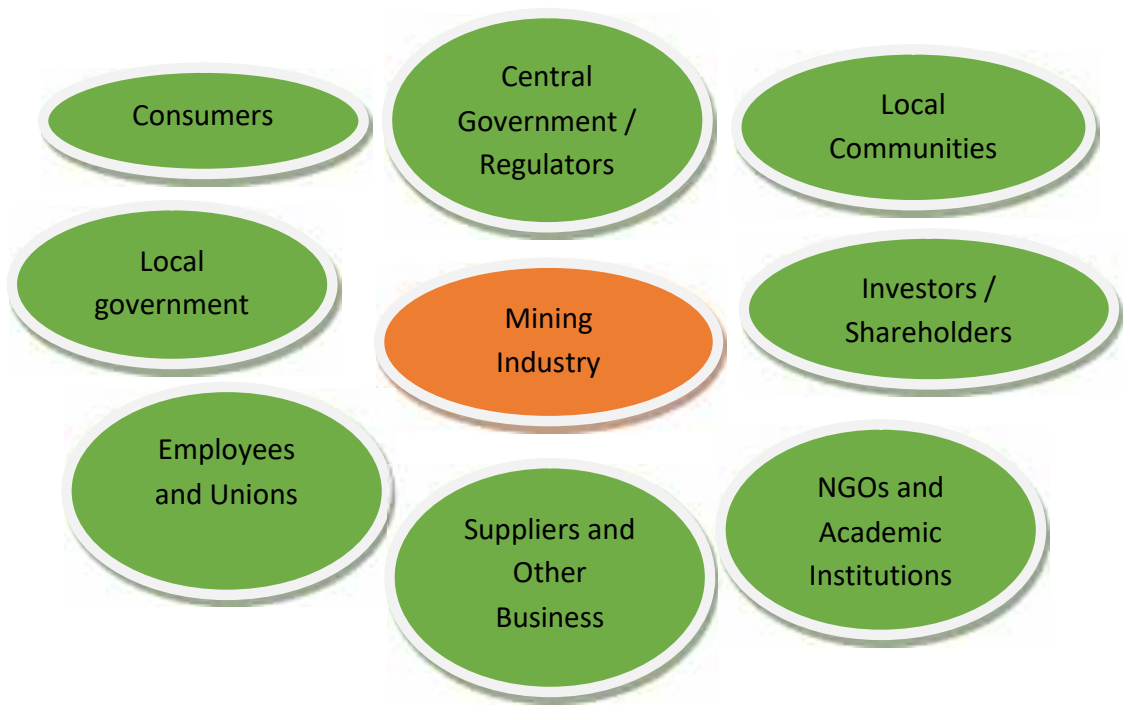


Figure 10. The stakeholder groups in mining industry

Identifying the impacts to company's stakeholders can be created by connecting between the material information and the interests of company's stakeholders. The economic performance of the company obviously affects the interests of investors or shareholders. The company's management should be able to act as an agent to manage the company's resources in order to meet the expectations of investors who acts as the principal. Informations about education and training of personnel will have an high impact on the interests of employees. In this context we can understand that the company's stakeholders can focus only on the information that will have a major impact on their behalf or have a high impact on their decision making process (Manetti, 2011).

\section{Information Materiality Map Based on Sustainability Report in Mining Industry in Indonesia}

In general, the information materiality map created by the analysis that has been done in previous stages and contains the material information in the context of sustainability reports in mining industry companies. The basic concept in the preparation of information materiality map is based on the perspective that the level of information materiality in sustainability report has strong relationship with the level of influential impact of the information against the interests of company's stakeholders. In the model of information materiality map will be contained a map that links between the types of information and the level of impact that can be felt by the company's stakeholders. In information materiality map model, will be included the level of impact that affect the interests of the mining industry stakeholders where the level of impact can be divided into three types, namely low, medium, and high. Low impact level can be defined that the material information had little impact on the interests of the company's stakeholders and so does the meaning of medium impact level and high impact level. The basis or reference for preparing information materiality map is based on the materiality map that was developed by SASB (Sustainability Accounting Standards Board). In the concept of materiality map was created by SASB contained information that applies to each industry. In SASB materiality map, we can see the material information for specific industry.

Information Materiality Map in Mining Industry in Indonesia

\begin{tabular}{|c|c|c|c|c|c|c|c|}
\hline $\begin{array}{c}\text { Material } \\
\text { Information in } \\
\text { Mining Industry }\end{array}$ & \multicolumn{7}{|c|}{ Mining Industry Stakeholders } \\
\cline { 2 - 7 } & Consumers & $\begin{array}{c}\text { Government/ } \\
\text { Regulator }\end{array}$ & Investor & $\begin{array}{l}\text { Employee } \\
\text { / Labor } \\
\text { Union }\end{array}$ & $\begin{array}{l}\text { Supplier / } \\
\text { Other } \\
\text { Organization }\end{array}$ & $\begin{array}{l}\text { Public Community } \\
\text { / Local Community }\end{array}$ & $\begin{array}{c}\text { NGOs } \\
\text { High } \\
\text { Growth }\end{array}$ \\
\hline $\begin{array}{c}\text { Regulatory } \\
\text { Compliance }\end{array}$ & Hedium & High & High & High & Medium & High & High \\
\hline $\begin{array}{c}\text { Employee } \\
\text { Safety and } \\
\text { Health }\end{array}$ & Low & High & High & High & Medium & Medium & High \\
\hline
\end{tabular}




\begin{tabular}{|c|c|c|c|c|c|c|c|}
\hline $\begin{array}{c}\text { Local } \\
\text { Community } \\
\text { Engagement }\end{array}$ & Low & High & Low & Medium & Low & High & High \\
\hline $\begin{array}{c}\text { Employee } \\
\text { Training and } \\
\text { Development }\end{array}$ & Low & High & Medium & High & Medium & Medium & High \\
\hline $\begin{array}{c}\text { Anti } \\
\text { Corruption }\end{array}$ & Medium & High & High & High & Low & High & High \\
\hline $\begin{array}{c}\text { Socio- } \\
\text { Economic } \\
\text { Contribution }\end{array}$ & Low & High & Low & Medium & Low & High & High \\
\hline $\begin{array}{c}\text { Environmental } \\
\text { Management } \\
\text { and } \\
\text { Performance }\end{array}$ & Low & High & Low & Low & Low & High & High \\
\hline $\begin{array}{c}\text { Biodiversity } \\
\text { Protection }\end{array}$ & Low & High & Low & Low & Low & High & High \\
\hline $\begin{array}{c}\text { Water and } \\
\text { Waste } \\
\text { Management }\end{array}$ & Low & High & Low & Medium & Low & High & High \\
\hline $\begin{array}{c}\text { Energy } \\
\text { Consumption }\end{array}$ & Low & High & Low & Low & Low & High & High \\
\hline
\end{tabular}

In preparation of this information materiality map, one type of information can be material for various type of company's stakeholders. Information about company's financial performance can be material for government or regulators, investors, and employees. Investor also concern about the information of financial performance because this kind of information has a strong relationship with their investment decisions. Employees have different interests which the economic performance of the company can be used as one measure of the companys's performance and the quality of human resources. Information on the anti-corruption and fraud prevention in the company's internal management is very material for all stakeholders of the company. It is certainly in accordance with the opinion of Kolk (2008) that the corporate governance is closely associated with the company's sustainability. If the company's management manage the company with anti corruption and anti fraud principle, the company's sustainability objectives will be achieved. The structure of information materiality map is determined by the assessment conducted by the company's management. The company's management should find out who is the group of stakeholders and determine what material aspects that influence the different stakeholder groups.

In general, group of company's stakeholders can be divided into two, the internal stakeholders and the external stakeholders. Supposedly the company's management should provide complete and comprehensive information to all the stakeholders. It is also a moral responsibility from management to manage the company based on company's stakeholders interests. Based on this principle, the function of corporate sustainability report is as a medium of communication between the company's management with the company's stakeholders. If the company's management improve the quality of their non-financial information, they will obtain two advantages, namely (1) the quality of financial information and non-financial information will be the same so the company's stakeholders can assess the company's more comprehensive than before and (2) stakeholders can create a good decision in accordance with the quality of financial information and non-financial information. It should be realized that one 
purpose of corporate reporting is to provide comprehensive information to all stakeholders of the company. Zhou (2011) stated that the number of the company's stakeholders will demonstrate the different interests and of course to accommodate this fact, company's management should report or disclose various data and information. The consequence is the time and the cost incurred to be larger, with the possibility of a small degree of effectiveness of specific information. Identification process of information materiality and its impact on company's stakeholders can be defined that company's management can focus on the material information that is required by the company's stakeholders. In this context, company's stakeholders will obtain the necessary information or material information in corporate sustainability report so the effectiveness of information becomes high for stakeholders decision making process. Another opinion related to the information materiality was submitted by Eccles et al. (2012) which explained that determine the materiality of the information should be made on the basis of companies or type of industry. Opinion of Eccles et al. (2012) supports a concept that sustainability principle of each company is different depends on the industry in which they operate. The concept of materiality is important issue when performing an audit on corporate sustainability report. Edgley et al. (2015) proposed an idea to adopt the concept of materiality of information in an audit of the company's social and environmental information.

\section{Conclusion}

The results of this study find that in the period from 2014 to 2016, material informations in sustainability report in mining industry are (1) economic growth, (2) regulatory compliance, (3) employee safety and health, (4) local community engagement, (5) employee training and development, (6) anti-corruption, (7) socioeconomic contribution, (8) environmental management and performance, (9) biodiversity protection, (10) waste management, (11) water management, and (12) energy consumption. Within this context, we can understand that the information materiality in corporate sustainability report is determined by the characteristics of the company, type of industry, and the characteristics of the company's stakeholders. All sampled of sustainability report has presented information about financial performance, social performance, and environmental performance very well. This fact will create an assumption that corporate sustainability report will be the basis for a draft of integrated reporting. The concept of integrated reporting is expected to be a new concept that emerged from the concept of sustainability reporting and build a new paradigm in corporate reporting context. The conclusion in this study is similar to the statement in the report of Ernst \& Young (2015) which states that sustainability reporting will continue to grow and in the future there will be a good combination between the financial reporting and non-financial reporting (a new concept of integrated reporting) in company business context.

\section{References}

Braam, G.J., L.U. de Weerd, M. Hauck, \& M.A. Huijbregts. 2016. Determinants of corporate environmental reporting: The importance of environmental performance and assurance. Journal of Cleaner Production. Vol. 129. Pp. 724-734. 
Brown, H.S., M. de Jong \& D.L. Levy. 2009. Building institutions based on information disclosure: lessons from GRI's sustainability reporting. Journal of Cleaner Production. Vol. 17. Pp. 571-580.

Eccles, R.G., M.P. Krzus, J. Rogers \& G. Serafeim. 2012. The need for sector-specific materiality and sustainability reporting standards. Journal of Applied Corporate Finance. Vol. 24. No. 2. Pp. 65-71.

Edgley, C., M.J. Jones, \& J. Atkins. 2015. The adoption of the materiality concept in social and environmental reporting assurance: A field study approach. The British Accounting Review. Vol. 47. No. 1. Pp. 1-18.

Ernst \& Young. Materiality and Sustainability Disclosure 2015 Key Insights from the Singapore Exchange Top 50. Singapore: Ernst \& Young.

GRI. 2015. Disclosures GRI G4 Sector Mining Sector. Amsterdam: GRI.

GRI \& RobecoSAM. 2015. Defining materiality: what matters to Reporters and investors. Amsterdam: GRI.

Hsu, C.W., W.H. Lee, \& W.C. Chao. 2013. Materiality analysis models in sustainability reporting: a case study at Lite-On Technology Corporation. Journal of Cleaner Production. Vol. 57. Pp. 142-151.

Khan, M., G. Serafeim, \& A. Yoon. 2016. Corporate sustainability: First evidence on materiality. The Accounting Review. Vol. 91. No. 6. Pp. 1697-1724.

Kolk, A. 2008. Sustainability, accountability and corporate governance: exploring Multinationals' reporting practices. Business Strategy and The Environment. Vol. 17. No. 1. Pp. 1-15.

Manetti, G. 2011. The quality of stakeholder engagement in sustainability reporting: empirical evidence and critical points. Corporate Social Responsibility and Environmental Management. Vol. 18. No. 2. Pp. 110-122.

Naraduhita, DC and T. Sawarjuwono. 2012. Corporate social responsibility: upaya memahami alasan dibalik pengungkapan CSR bidang pendidikan. Jurnal Akuntansi dan Auditing. Vol. 8. No. 2. Pp. 95-108.

Nuryaman. 2013. The effect of corporate social responsibility activities on profitability and stock price (studies on the companies listed on Indonesia Stock Exchange). $4^{\text {th }}$ International Conference on Business and Economic Research (4th ICBER 2013). Proceeding. Pp. 756-769.

Qureshi, N.Z., D. Kulshrestha, and S.B. Tiwari. 2012. Environmental accounting and reporting: an essential component of business strategy. Asian Journal of Research in Banking and Finance. Vol. 2. No. 4. Pp. 85-95.

Zhou, Y. 2011. Materiality approach in sustainability reporting: applications, dilemmas, and challenges. $1^{\text {st }}$ World Sustainability Forum, November 1 to 30, 2011. 